\title{
Haunting Encounters
}





\title{
Haunting Encounters
} The Ethics of Reading across Boundaries of Difference

\author{
Joanne Lipson Freed
}

Cornell University Press

Ithaca and London 


\section{Copyright @ 2017 by Cornell University}

All rights reserved. Except for brief quotations in a review, this book, or parts thereof, must not be reproduced in any form without permission in writing from the publisher. For information, address Cornell University Press, Sage House, 512 East State Street, Ithaca, New York 14850.

First published 2017 by Cornell University Press

Printed in the United States of America

Library of Congress Cataloging-in-Publication Data

Names: Freed, Joanne Lipson, 1983- author.

Title: Haunting encounters : the ethics of reading across boundaries of difference / Joanne Lipson Freed.

Description: Ithaca : Cornell University Press, 2017. | Includes bibliographical references and index.

Identifiers: LCCN 2017013435 (print) | LCCN 2017018722 (ebook) | ISBN 9781501713828 (pdf) | ISBN 9781501713835 (ret) | ISBN 9781501713767 | ISBN 9781501713767 (cloth : alk. paper)

Subjects: LCSH: Ghosts in literature. | Supernatural in literature. | Psychic trauma in literature. | Memory in literature. | Difference (Philosophy) in literature. | Transnationalism in literature. | Ghost stories - History and criticism. | American fiction - 20th centuryHistory and criticism. | American fiction-21st century-History and criticism. | Commonwealth fiction (English)-20th centuryHistory and criticism. | Commonwealth fiction (English)-21st century-History and criticism.

Classification: LCC PS374.G45 (ebook) | LCC PS374.G45 F74 2017 (print) | DDC 813/.0873309—dc23

LC record available at https://lccn.loc.gov/2017013435

Cornell University Press strives to use environmentally responsible suppliers and materials to the fullest extent possible in the publishing of its books. Such materials include vegetable-based, low-VOC inks and acid-free papers that are recycled, totally chlorine-free, or partly composed of nonwood fibers. For further information, visit our website at cornellpress.cornell.edu.

Cover illustration: Past Present 3, 2015, oil on canvas, $200 \times 200 \times 10 \mathrm{~cm}$ Courtesy Andréhn-Schiptjenko, Stockholm 
For James and Nora 
